\title{
Micropaleontological study of the Moroccan Mediterranean western coastline foraminifera and their morphological abnormalities
}

\author{
Haitam Afilal ${ }^{l,}$, Abdellah Trankil ${ }^{1}$, Saida Bouzid $^{l}$, and Abdelhamid Rossi ${ }^{l}$ \\ ${ }^{1}$ Faculty of Sciences and Techniques of Tangier, Abdelmalek Essaadi University, Tetouan, Morocco.
}

\begin{abstract}
In order to contribute to the identification of the current faunistic composition of the Moroccan Mediterranean western coastline foraminifera, sediment from 4 stations have been analyzed, along with some abiotic parameters $(\mathrm{pH}$, dissolved oxygen, temperature, and salinity), In order to characterize their populations, different Ecological indices were calculated and compared in the various samples. A total of 3451 individuals belonging to 14 species were recognized (90,26\% hyaline, 9,74\% porcelaneous, and none agglutinated test was found), all assemblages were dominated mainly by Elphidium crispum, Ammonia beccarii, and subordinately by Quinqueloculina spl and Heterolepa dutemplei. All sampling sites showed remarkable similarity in the Foraminiferal assemblages, and the Oued Nigro station is considered the wealthiest and densest site, whereas Oued Martil records the lowest values of those parameters. On the other hand, the Sample from M'diq presents the lowest diversity index even if it is the second in terms of density. The faunistic analysis had also allowed the observation of some morphological abnormalities only found in the Oued Nigro station, affecting some individuals' tests. A small-sized chamber mainly manifests the abnormal appearances in the spiral whorls and calcification defects in the calcareous wall.
\end{abstract}

\section{Introduction}

At the interface of oceanic, terrestrial, and atmospheric domains, coastal zones offer a unique ecological richness, where the foraminifera assemblages represent more than $50 \%$ of the total sediment biomass [1].

Although current foraminifera species have been widely studied in the Mediterranean Sea [2-3], their assemblages in the Moroccan coasts are still poorly known. In this context, this study aims to describe the faunistic composition of Foraminifera sheltering the Moroccan Mediterranean coastline fringe. To this end, sediment from 4 stations has been analyzed.

\section{Objectives}

Foraminiferal assemblages present a great scientific interest, given their great potential as biostratigraphical and environmental indicators.

Therefore, this study is of great scientific interest since it aims to draw up an inventory of the species sheltering the Mediterranean coastal areas and identify their morphological abnormalities.

\section{Methodology}

\subsection{Study area and sampling sites}

The study area is located between Oued Nigro and Oued Martil, extending along $25 \mathrm{~km}$ of coast. In April 2021, a total of 5 samples were collected from 4 stations along the coastline fringe. Sampling points locations were chosen based on their proximity to towns, ports, and discharges from continental emissaries.

One sample was collected from each station 10 meters from the coastal fringe during low tide conditions, except Oued Nigro's station, where an additional sample was taken from its mouth. (Fig. 1)

\subsection{Field sampling}

Samples were collected and stored in plastic bags, using a $75 \mathrm{~mm}$ diameter PVC core $10 \mathrm{~cm}$ deep. $\mathrm{pH}$, dissolved oxygen, temperature, and salinity data of the surface water from each sampling point were measured using a multiparameter.

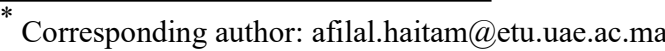




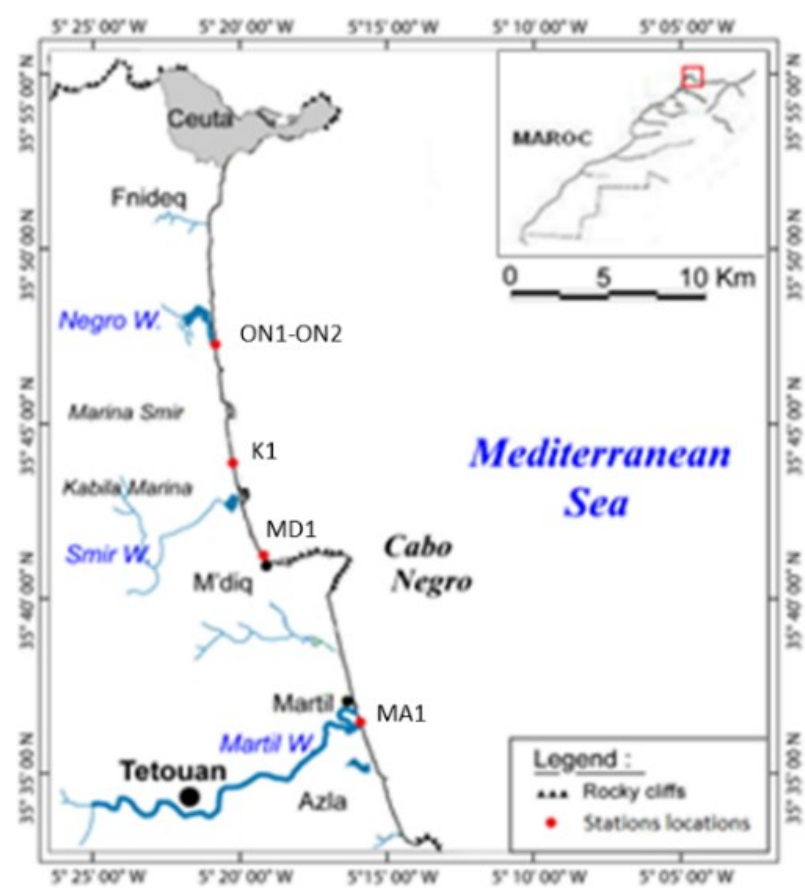

Fig. 1. Location of the sampling stations along the Moroccan Mediterranean Western coastline.

\subsubsection{Individuals extraction and identification}

Each sample was spread on a picking tray, and individuals were picked systematically from side to side along the rows. We were using a thin brush under a binocular loupe. All individuals were picked from the sample and placed in cells to identify based on previous studies on benthic foraminiferal assemblages [4-5].

\section{Results and Discussion}

\subsection{Foraminifera inventory}

Three thousand four hundred fifty-one individuals belonging to 14 species were recognized $(90,26 \%$ hyaline, $9,74 \%$ porcelaneous, and none agglutinated test was found). All assemblages were largely dominated by Elphidium crispum (49,58\%), Ammonia beccarii $(26,95)$, and subordinately by Quinqueloculina sp1 $(9,34 \%)$ and Heterolepa dutemplei (7,01\%). (Table 1, Fig .1)

Table 1. Distribution (in absolute numbers) of the foraminifera species of the Mediterranean Western coastline in $50 \mathrm{~g}$ of sediment (the table indicates the corresponding identification used in the inventory plate).

\begin{tabular}{|l|c|c|c|c|c|c|}
\hline \multirow{2}{*}{ Species } & \multirow{2}{*}{ ID } & \multicolumn{5}{|c|}{ Station } \\
\cline { 3 - 7 } & & \multicolumn{2}{|c|}{ Oued Negro } & Kabila & M'diq & Martil \\
\cline { 3 - 7 } & ON1 & ON2 & K1 & MD1 & MA1 \\
\hline $\begin{array}{l}\text { Elphidium } \\
\text { crispum }\end{array}$ & $\mathrm{A}$ & 238 & 881 & 94 & 490 & 8 \\
\hline $\begin{array}{l}\text { Ammonia } \\
\text { beccarii }\end{array}$ & $\mathrm{B}$ & 210 & 349 & 131 & 236 & 4 \\
\hline Ammonia tepida & $\mathrm{C}$ & 4 & 14 & 0 & 0 & 0 \\
\hline
\end{tabular}

\begin{tabular}{|l|c|c|c|c|c|c|}
\hline $\begin{array}{l}\text { Heterolepa } \\
\text { dutemplei }\end{array}$ & $\mathrm{D}$ & 19 & 94 & 11 & 117 & 1 \\
\hline $\begin{array}{l}\text { Lenticulina } \\
\text { vortex }\end{array}$ & $\mathrm{E}$ & 2 & 31 & 0 & 33 & 0 \\
\hline $\begin{array}{l}\text { Gyroidina } \\
\text { leavigata }\end{array}$ & $\mathrm{F}$ & 6 & 81 & 5 & 21 & 0 \\
\hline Gen 1 & $\mathrm{G}$ & 2 & 33 & 0 & 0 & 0 \\
\hline Triloculina sp1 & $\mathrm{H}$ & 2 & 4 & 4 & 3 & 1 \\
\hline $\begin{array}{l}\text { Quinqueloculina } \\
\text { sp1 }\end{array}$ & $\mathrm{I}$ & 44 & 170 & 29 & 71 & 8 \\
\hline $\begin{array}{l}\text { Cancris } \\
\text { auriculus }\end{array}$ & $\mathrm{J}$ & 0 & 3 & 0 & 0 & 0 \\
\hline lenticulina sp2 & $\mathrm{K}$ & 0 & 2 & 0 & 0 & 0 \\
\hline $\begin{array}{l}\text { Quinqueloculina } \\
\text { sp2 }\end{array}$ & $\mathrm{L}$ & 0 & 1 & 0 & 0 & 0 \\
\hline Cibicides & $\mathrm{M}$ & 0 & 1 & 0 & 0 & 0 \\
\hline $\begin{array}{l}\text { Globigerina } \\
\text { bulloides }\end{array}$ & $\mathrm{N}$ & 0 & 1 & 0 & 0 & 0 \\
\hline \multicolumn{1}{|c|}{ Total } & - & 27 & 1665 & 274 & 971 & 22 \\
\hline
\end{tabular}

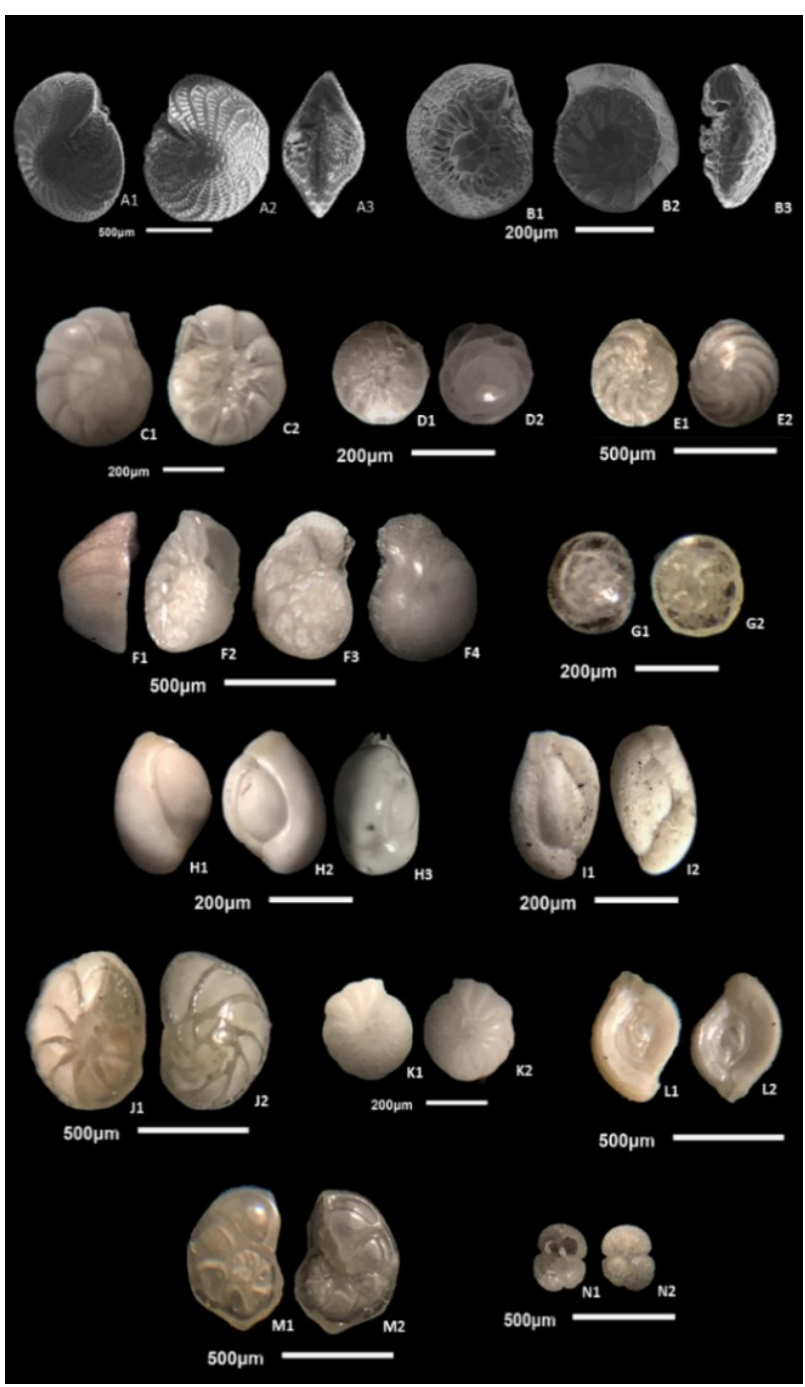

Fig.1. Photos of foraminifera species from the Mediterranean coastline fringe between Oued Nigro and Oued Martil. 


\subsection{Physico-chemical parameters and ecological indices}

For each station, the temperature, dissolved oxygen, salinity, and $\mathrm{pH}$ data have been measured to define the environmental conditions during sample collection. (Table 2)

In order to characterize the faunistic composition, the total foraminiferal density and the specific richness (number of different species per sample) were calculated; as for the diversity, we used the ShannonWiener index, which links the number of species to the assemblage density. (Fig. 2)

Table 2. The physicochemical parameters of the shallow water at each sampling point.

\begin{tabular}{|c|c|c|c|c|c|}
\hline \multirow{2}{*}{ Parameters } & \multicolumn{5}{|c|}{ Station } \\
\cline { 2 - 6 } & Oued Negro & Kabila & M'diq & Martil \\
\cline { 2 - 6 } & ON1 & ON2 & KA1 & MD1 & MA1 \\
\hline $\begin{array}{c}\text { Temperature } \\
\mathrm{c}^{\circ}\end{array}$ & 20 & 18,4 & 18,3 & 19,7 & 19,3 \\
\hline $\begin{array}{c}\text { O2 dissolved } \\
\text { mg/1 }\end{array}$ & 10,5 & 7,22 & 6,8 & 7,96 & 4,92 \\
\hline $\begin{array}{c}\text { Salinity ppm } \\
\text { pH }\end{array}$ & 28,6 & 35,2 & 36,87 & 37,13 & 27,73 \\
\hline & 8,25 & 8,4 & 8,37 & 8,33 & 7,97 \\
\hline
\end{tabular}

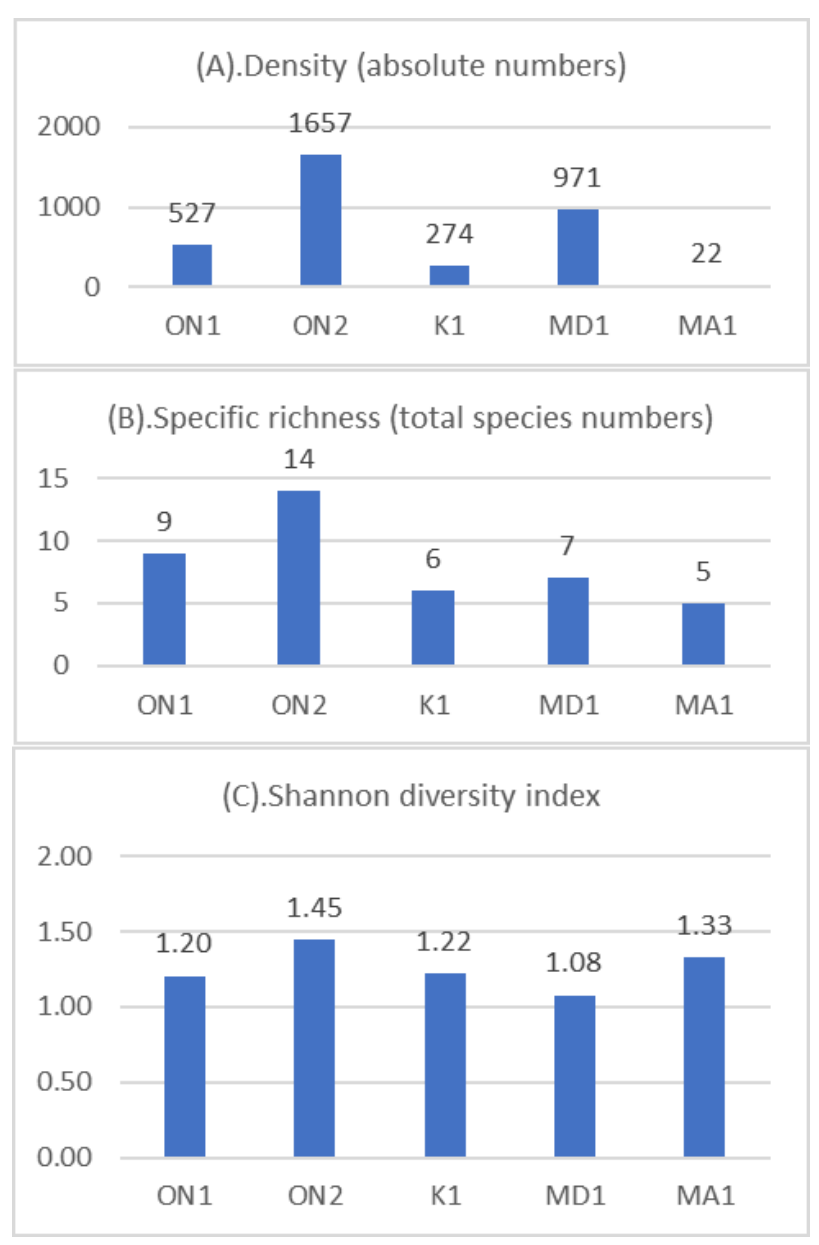

Fig. 2. (A) Total foraminiferal density, (B) the specific richness, (C) the Shannon-Wiener diversity index for the four sampling stations.
The samples analyses showed significant similarity in the foraminiferal assemblages among all stationsmoreover, highly variable faunal densities vary between 22 to 1665 individuals.

Increasing in the specific richness (9 to 14) and density (527 to 1657 ) from Oued Nigro mouth towards the sea is observed, considered the richest and the densest site among all samples.

The very low density and richness are found at Oued Martil station with only five species and a total of 22 individuals,

On the other hand, the Sample from M'diq presents the lowest diversity index even if it is the second in terms of density.

The increase of individuals and species from upstream to downstream in the Oued Nigro sediment is due to the increasing salinity in the water since it represents a factor of influence on the distribution of the foraminifera assemblages [6].

Regarding the Oued Martil station, apart from its low density compared to other stations, most of the individuals were degraded and fractured, and probably none of them have been alive during the samples collection due to the great pollution load received in this region, according to many studies [7].

The physicochemical parameters collected shows a normal environmental condition, and therefore the observed changes in the foraminiferal associations may be due to other factors as hydrodynamic, granulometric, organic matter concentration

\subsection{Morphological abnormalities}

During the faunistic analysis, some abnormalities affecting some individuals caught the attention, especially that those abnormalities were seen only in the Oued negro station. The abnormal appearances observed had affected only the abundant species Elphidium crispum and Ammonia beccarii. Those abnormalities are mainly represented in a small size chamber in the spiral whorls and calcification defects in the calcareous wall. (Fig. 3)

\subsubsection{Small size chambers}

It results by the presence of one chamber or more with a smaller size than the average, thus breaking the regularity of the spiral (Fig. 3: a1, a2, b1, b2), showing that at the time when the individual was building or preparing to build this chamber a physiological disorder occurred. The small chamber does not always occupy the same rank in the spire. This can be explained by the fact that individuals in the same population do not all appear simultaneously and that, in the same generation, they do not necessarily have a synchro growth.

\subsubsection{Calcification defects}

The Calcification defect is manifested in the form of folding or crumpling in the calcareous wall, as if the wall had been «softened», then recalcified while keeping a 
«crumpled» aspect. (Fig. 3: b3, b4). This anomaly only concern Ammonia beccarii, and it does not appear to be due to a crash caused by a shock because no fracture was detected

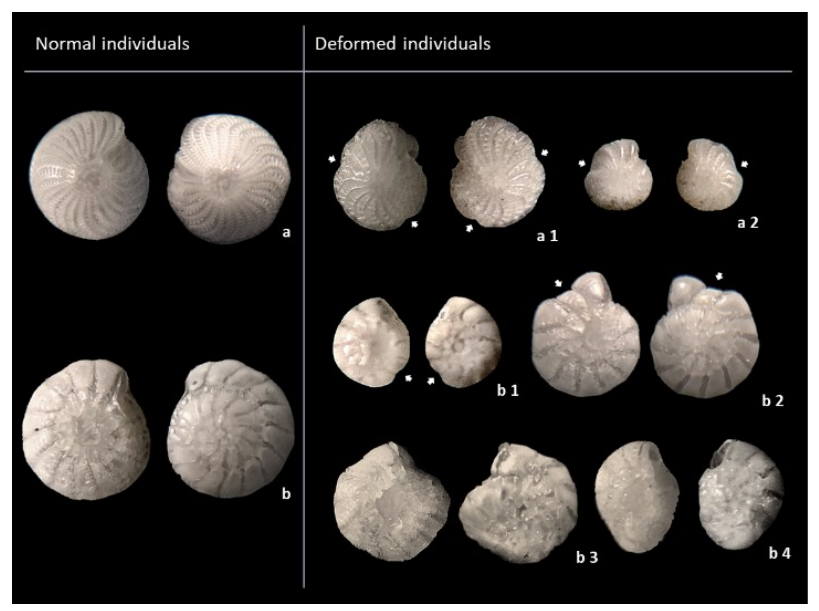

Fig. 3. Photos of foraminifera species with morphological abnormalities.

The small chamber of the individuals experiencing a slowdown in growth corresponds probably to the first chamber built after a disturbance in the conditions of the environment. The crumpling aspect may indicate transient acidification of the environment. Since the calcareous wall behaves like it was partially decalcified, collapsed, then recalcified, keeping a deformed aspect.

It appears that the Mediterranean western coastline fringe has a similar foraminiferal composition with a highly variable faunal density.

The morphological abnormalities detected in some individuals' tests show how sensitive these organisms are to environmental disturbances. All the abnormal appearances can be recorded thanks to the fossilized nature of tests in sediment after death.

\section{Conclusion}

The determined foraminiferal assemblages will give reliable indications on the environmental quality since the ecological characteristics of the different species are different enough to obtain reliable information about the environmental conditions, as shown in a wide range of papers on benthic foraminiferal ecology [8-9].

Apart from the faunistic analysis, this study allowed detecting a certain number of deformations of some individual's test. The number of individuals deformed is low since the samples were taken for a completely different purpose than morphological analysis. They were intended for the inventory of the microfauna. That is why the coring sampling method was chosen. Otherwise, a sampling by skimming the surface could have been more relevant for the morphological study. It should be noted that the detection of abnormalities is not always possible; a certain number of anomalies likely to affect first chambers can be masked by the embracing chambers of the subsequent whorls giving a regular aspect even that it is deformed from the inside.

\section{Acknowledgments}

I am pleased to address a special thanks to Pr. Rezqi Halima from the Mohammed Premier University of Oujda for her help in verifying the species identified.

\section{References}

1. A.J. Gooday, A.E. Rathburn. Temporal variability in living deep-sea Foraminifera: a review. EarthScience Reviews 46, 187-212. (1999)

2. J.P. Debenay, E. Tsakiridis, R. Soulard, H. Grossel,. Factors determining the distribution of foraminiferal assemblages in Port Joinville Harbor (Ile d'Yeu, France): the influence of pollution. Mar. Micropaleontol. 43, 75-118 (2001)

3. R. Coccioni, F. Frontalini, A. Marsili, D. Mana, Benthic Foraminifera and trace element distribution: a case-study from the heavily polluted lagoon of Venice (Italy). Mar. Pollut. Bull. 59, 257-267 (2009)

4. A.R. Loeblich, H. Tappan, Foraminiferal genera and their classification. New York: Van Reinhold. (1987)

5. J.W. Murray, Ecology and distribution. In: BENTHOS'90, Tokai University Press, Sendai. (1991)

6. J.W. Murray, Syndepositional dissolution of calcareous Foraminifera in modern shallow water sediments. Marine micropaleontology 15, 117-121 (1989)

7. M. Blinda, Land-based pollution of the northwest coast of Morocco between Tangier and Tetouan: Characterization, Impact on the Environment and Solutions Proposal (2007)

8. J.W. Murray. Ecology and Applications of Benthic Foraminifera. Cambridge University Press, Cambridge, 426. (2006)

9. F.J. Jorissen, C. Fontanier, E. Thomas. Chapter seven paleoceanographicalproxies based on deepsea benthic foraminiferal assemblage characteristics. In:Hillaire-Marcel, C., De Vernal, A. (Eds.), Paleoceanography of the Late Cenozoic.Developments in Marine Geology, Elsevier,263-325 (2007) 